\title{
Pengudusan Progresif Orang Percaya Menurut 1 Yohanes 1:9
}

\author{
Nurnilam Sarumaha \\ Sekolah Tinggi Teologi Pelita Bangsa, Jakarta \\ nurnilam150676@gmail.com
}

\begin{abstract}
One of God's will in human life is to live in holiness, even though it is not an easy thing to maintain a holy life perfectly. However, holiness can be progressive. This study aims to show the importance of progressive sanctification of believers. By using a descriptive method of analysis of the biblical text, especially 1 John 1: 9, it can be concluded that believers must progressively sanctify. Sanctification is progressively a reflection of the growth of the Christian faith toward maturity.
\end{abstract}

\begin{abstract}
Abstrak
Salah satu kehendak Tuhan dalam hidup manusia adalah hidup di dalam kekudusan, sekalipun bukanlah hal yang mudah mempertahankan hidup yang kudus secara sempurna. Namun demikian, kekudusan itu dapat bersifat progresif. Kajian ini bertujuan untuk menunjukkan pentingnya pengudusan secara progresif orang percaya. Dengan menggunakan metode deskriptif analisis terhadap teks Alkitab, khususnya 1 Yohanes 1:9, maka dapat disimpulkan bahwa orang percaya harus mengalami pengudusan secara progresif. Pengudusan secara progresif merupakan refleksi pertumbuhan iman Kristen menuju kedewasaan.
\end{abstract}

Article History

Submit:

19 February 2019

Revised:

05 April 2019

Accepted:

25 April 2019

Keywords (kata kunci):

holiness;

sanctifying; progressive sanctification;

$\sin$

dosa;

kekudusan; kudus;

pengudusan progresif

\section{Pendahuluan}

Istilah pengudusan dalam teologi sistimatika, dapat dibagi atas tiga bagian, yaitu pengudusan awal, pengudusan progresif dan pengudusan akhir (final). ${ }^{1}$ Pengudusan awal, terkait dengan langkah Allah yang mengambil inisiatif untuk memisahkan manusia dari dosa. Kedua, pengudusan secara pengalaman, yang juga lazim disebut progressive sanctification, merupakan tindakan manusia dalam menjaga kekudusan hidupnya. Ketiga, pengudusan final atau perfected sanctification menunjuk pada kedewasaan atau kesempurnaan total di saat Yesus datang kedua kali. Hidup dalam kekudusan merupakan kehendak Tuhan pada manusia. Hal ini bukan tanpa alasan, mengingat manusia diciptakan menurut rupa dan gambar Allah (Kej.1:26). ${ }^{2}$

${ }^{1}$ Chris Marantika, Doktrin Keselamatan Dan Kehidupan Rohani (Yogyakarta: Iman Press, 2002), 141-144.

${ }^{2}$ Dolf Tiyono, "Memahami Imago Dei Sebagai ‘ Golden Seed ," EPIGRAPHE: Jurnal Teologi dan

Pelayanan Kristiani 1, no. 1 (2017): 39-54,

http://www.stttorsina.ac.id/jurnal/index.php/epigraphe/article/view/8. 
Penegasan tentang hidup kudus dapat juga dilihat dalam 1 Petrus 1:16 yang berkata: “...Kuduslah kamu, sebab Aku kudus." Oleh karena Allah yang menciptakan manusia adalah kudus maka manusia ciptaan-Nya juga haruslah kudus. Ada beberapa hal yang menjadi problem statement dalam menyikapi hidup kudus di antaranya adalah: Pertama, sekalipun manusia telah dikuduskan oleh Allah, telah dipisahkan dari dosa melalui pengorbanan AnakNya Yesus Kristus sehingga ia disebut sebagai orang percaya, namun unsur kedagingan menjadikan orang yang sudah percaya sekalipun tidak luput dari kegagalan dan perbuatan jatuh dalam dosa (Mat. 26:41). Kehidupan manusia adalah kehidupan yang memiliki roh dan tubuh (daging). ${ }^{3}$ Kecenderungan kehidupan roh manusia yang telah hidup di dalam Tuhan adalah kecenderungan mengikuti kehendak Allah namun sebaliknya kehidupan di dalam daging menjadikan manusia lemah dan mudah jatuh di dalam dosa.

Kedua, dalam menjalani kehidupan ini, merupakan hal yang sangat mustahil untuk dapat menjaga hidup kudus selamanya, sampai Tuhan Yesus datang untuk kedua kali. Dalam Pengkhotbah 7:20 dikatakan: "Sesungguhnya, di bumi tidak ada orang yang saleh: yang berbuat baik dan tidak pernah berbuat dosa." Ini membuktikan bahwa orang yang telah percaya dan telah mengenakan kekudusan dari Allah tidak luput dari perbuatan dosa.

Ketiga, tuntutan firman Tuhan dalam hidup orang percaya adalah mengejar kekudusan (Ibr. 12:14). Hal yang paling esensial dalam hidup orang percaya (manusia yang sudah mengalami pembaharuan) adalah ia harus mengenakan manusia baru yang telah diciptakan menurut kehendak Allah di dalam kebenaran dan kekudusan yang sebenarnya. ${ }^{4}$ Hal ini memberi pengertian bahwa setiap orang percaya yang sudah dikuduskan Allah harus berusaha menjaga kekudusan hidupnya.

Beberapa poin di atas menekankan betapa manusia di satu sisi adalah fana dan seringkali jatuh dalam dosa, dan di sisi lain manusia harus hidup dalam kekudusan sesuai dengan kehendak Allah. Pembahasan kekudusan secara progresif merupakan hal penting untuk menyadarkan manusia, khususnya orang percya, untuk hidup dalam kehendak Allah, walaupun di sisi lain mereka tetap memiliki keterbatasan kedagingan atau manusiawi. Pokok ini dapat menjadi referensi dalam gereja nantinya, mendorong umat Tuhan mendorong kekudusan secara progresif.

Pembahasan tentang tema kekudusan merupakan hal yang umum dalam dunia teologi Kristen. Banyaknya tema-tema tersebut lebih berorientasi pada konsep kekudusan itu sendiri seperti yang dibahas oleh Zulkisar Pardede pada penekanan konsep kekudusan meurut kitab Yosua ${ }^{5}$; namun penekanan pembahasan ini lebih kepada kekudusan para hamba Tuhan sebagai pemimpin. Halim Wiryadinata membahas kekudusan dalam kaitannya dengan

\footnotetext{
${ }^{3}$ Nichole A. Murray-Swank, Kenneth I. Pargament, and Annette Mahoney, "At the Crossroads of Sexuality and Spirituality: The Sanctification of Sex by College Students," The International Journal for the Psychology of Religion 15, no. 3 (2005).

${ }^{4} J$ oseph Christ Santo, "Makna Dan Penerapan Frasa Mata Hati Yang Diterangi Dalam Efesus 1:18-19," Jurnal Teologi Berita Hidup 1, no. 1 (2018): 1-12, www.e-journal.sttberitahidup.ac.id/index.php/jbh. Band: Halim Wiryadinata, "An Understanding the Pauline Christology Significance of Firstborn (Protokos) In The Light of Paschal Theology : Critical Evaluation on Colossian 1 : 15-20," KURIOS (Jurnal Teologi dan Pendidikan Agama Kristen) 4, no. 1 (2018): 14-25, http://www.sttpb.ac.id/ejournal/index.php/kurios/article/view/33.

${ }^{5}$ Zulkisar Pardede, "Rancang Bangun Teologi 'Kekudusan’ Tentang Hamba Tuhan Sebagai Pemimpin Kristen Menurut Kitab Yosua,” KHARISMATA: Jurnal Teologi Pantekosta 1, no. 2 (2019): 100-117, http://www.e-journal.stajember.ac.id/index.php/kharismata/article/view/20.
} 
kebenaran dalam Roma. ${ }^{6}$ Di tempat lain, pembahasan kekudusan pun dikatikan sebagai salah satu karakteristik jemaat mula-mula ${ }^{7}$, di mana gereja saat ini banyak yang mengambil patron darinya. Namun semua pembahasan tersebut tidak memberikan penekanan pada proses kekudusan yang harus dihidupi oleh orang percaya sebagai sebuah proses dalam progressive sanctification.

Itulah sebabnya pembahasan ini akan menambahkan akumulasi pengetahuan dalam bidang teologi praksis, khususnya menerapkannya dalam kehidupan gerejawi, mendorong umat Tuhan untuk mengejar hidup kudus. Penekanan pembahasan ini adalah pada proses kekudusan yang bersifat progresif atau bertahap sesuai dengan pergumulan orang percaya dalam kehidupannya masing-masing. Artikel ini menggunakan konsep yang ada pada teks 1 Yohanes 1:19 sebagai dasar untuk melakukan pengudusan progresif. Pengudusan progresif terjadi bila ada pengampunan dosa, dan pengampunan dosa terjadi jika ada pengakuan dosa

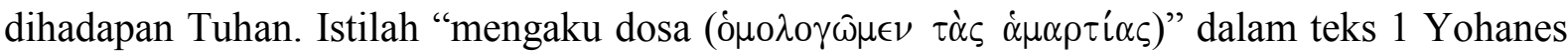
1:9 menuntut orang percaya memiliki inisiatif dari dirinya sendiri untuk mengakui segala dosa dan pelanggarannya sehingga kekudusan hidupnya tetap terjaga setiap hari.

\section{Metodologi}

Artikel ini merupakan penelitian kualitatif yang bersifat kajian terhadap teks Alkitab, khususnya dalam surat 1 Yohanes 1:9. Metdoe yang digunakan adalah deskriptif analisis, di mana teks 1 Yohanes 1:9 digunakan untuk mendeskripsikan konsep pengudusan yang diawali dengan pengakuan dosa. Teks tersebut dianalisis dengan pendekatn eksegetis sehingga diperoleh pemahaman tentang pentingnya pengudusan progresif bagi orang percaya.

Teks 1 Yohanes 1:9 berbunyi: "Jika kita mengaku dosa kita maka Ia adalah setia dan adil sehingga Ia akan mengampuni segala dosa kita dan menyucikan kita dari segala kejahatan kita." Kata "mengaku" dalam bahasa Yunani diartikan sebagai ó $\mu$ o $о \gamma \varepsilon ́ \omega$ (homologeo).

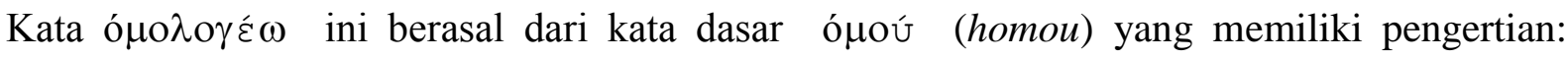
"tempat atau waktu yang sama, bersama-sama," sementara kata

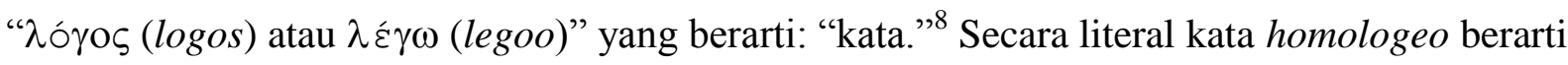
"berkata sesuatu" William D. Mounce mengartikan istilah ó o $_{\text {o }} \gamma \varepsilon \dot{\varepsilon} \omega$ dapat sebagai "berbicara dengan."10

Dalam penggunaannya, kata ó o $\mathrm{o} \gamma \tilde{\varepsilon} \omega$ memiliki arti yang sangat luas sekali. Pertama, kata promisse, assure artinya janji, jamin tanggung. Hal ini dapat dilihat dalam janji Allah kepada Abraham untuk membuat Abraham menjadi bangsa yang besar (Kis. 7:17), janji dalam bentuk sumpah (Mat. 14:7); hal ini berkaitan dengan janji Herodes kepada anaknya perempuan Herodias yang meminta kepala Yohanes pembabtis. Janji yang sungguh-sungguh.

\footnotetext{
${ }^{6}$ Halim Wiryadinata, “A Critical Analysis of God ' S Righteousness in Romans $1: 16$-17,” KURIOS (Jurnal Teologi dan Pendidikan Agama Kristen) 2, no. 1 (2014): 16-17, www.sttpb.ac.id/ejournal/index.php/kurios.

${ }^{7}$ Harls Evan R. Siahaan, “Karakteristik Pentakostalisme Menurut Kisah Para Rasul,” DUNAMIS: Jurnal Teologi dan Pendidikan Kristiani 2, no. 1 (2017): 12-28, www.sttintheos.ac.id/e-journal/index.php/dunamis. Band: Sonny Eli Zaluchu, "Eksegesis Kisah Para Rasul 2:42-47 Untuk Merumuskan Ciri Kehidupan Rohani Jemaat Mula-Mula Di Yerusalem,” EPIGRAPHE: Jurnal Teologi dan Pelayanan Kristiani 2, no. 2 (2018): 72 82, accessed November 1, 2018, http://www.stttorsina.ac.id/jurnal/index.php/epigraphe.

${ }^{8}$ James Strong, The New Strong's Exhaustive Concordance, n.d., 36.

${ }^{9}$ W.E. Vine, Vine Expository Dictionary of Old \& New Testament Words, n.d., 216.

${ }^{10}$ William D. Mounce, The Analytical Lexikon To The Greek (Michigan: London Pub.House, 1993), 338.
} 
Kedua, kata agree, admit artinya mengakui. Mengakui bahwa mereka dulu hanya orang asing (Ibr. 11:13). Kita mengakui bahwa kita tidak menerima anugrah. Ketiga, kata confess artinya mengakui. Dalam bahasa hukum membuat setuju atau menyetujui (Kis. 24:14). Peralihan (transisi) dari pengertian bagian kedua di atas, mungkin ilustrasi melalui kewibawaan aksi Yohanes pembaptis. Dan juga dalam kepercayaan dan penggunaan moral "jika kita mengaku dosa kita" (1Yoh1:9).

Keempat, kata declare artinya mengumumkan, menerangkan, melaporkan (bersifat umum). Kata confess yaitu mengakui, juga mengakui seseorang itu adalah; ... saya akan mengatakan dengan terus terang (Mat. 7:23). Mereka mengklaim mengenal Allah (Tit. 1:16). Mereka mengakui semua tentang mereka (Kis. 23:8). Hal ini juga mengenai Kristus atau pengajaran tentang gereja-Nya. Jika kamu mengakui Yesus sebagai Tuhan (Rom. 10:9). Mengakui bahwa Dia adalah Mesias (Yohanes 9:22). Mengakui bahwa Yesus Kristus akan datang dalam cahaya (1Yohanes 4:2). Seseorang mangakui atau seseorang mengumumkan bahwa akan datang seseorang (1Yohanes 3:23; 4:3), jika kita mengaku akan kesiapan-Nya dimana kita akan diselamatkan ( 1Yohanes 12:42; 1Timotius 6:12). Kelima, kata praise artinya memuji, pujian. Istilah kata yang digunakan dalam surat Ibrani. Hasil dari pujian membawa pujian bagi nama-Nya. ${ }^{6}$

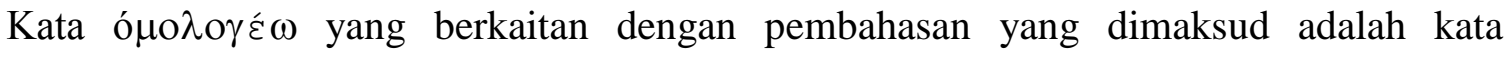
"pengakuan" yang berkaitan dengan iman percaya dan moral seseorang yang jatuh di dalam dosa tetapi mendapat pengampunan oleh karena statusnya orang-orang yang sudah dikuduskan secara posisi. Orang-orang yang sudah percaya tetapi masih jatuh dalam dosa harus menghadap Tuhan dan memberikan suatu pengakuan yang berasal dari hati yang tulus karena melanggar kekudusan Allah. Orang-orang percaya tersebut harus berbicara dengan Tuhan, dengan hati yang hancur atas segala apa yang telah diperbuatnya yang melanggar kekudusan Allah.

Pengudusan secara pengalaman meliputi partisipasi dan tanggung jawab penuh dari orang-orang percaya. Rasul Paulus berkata oleh karena orang-orang percaya telah dikuduskan dalam Kristus Yesus, maka orang-orang percaya telah memiliki janji-janji Allah dalam hidup mereka. Oleh sebab itu orang-orang percaya harus menyucikan dirinya dari segala pencemaran jasmani dan rohani sehingga menyempurnakan kekudusan tersebut dengan takut akan Tuhan (band. 2 Kor. 7:1). Orang-orang percaya yang telah dikuduskan dalam Kristus Yesus harus memiliki tanggung jawab yang besar terhadap dirinya sendiri, harus bertanggung jawab dengan segala tindakannya. Oleh sebab itu, orang-orang percaya harus berperang melawan dosa, baik dalam aspek tubuh maupun pikiran (Rm. 12:1-2). Artikel ini lebih memokuskan pada analisis leksikal yaitu berusaha menemukan arti dan makna kata ó $\mathrm{o} \lambda \mathrm{o} \gamma \tilde{\varepsilon} \omega$ dalam 1 Yohanes 1:9.

\section{Pembahasan}

Pengudusan secara pengalaman merupakan proses dalam hidup setiap orang percaya. Dikatakan proses karena orang-orang percaya masih tinggal di dunia, dimana dunia sangatlah bertentangan dengan keberadaan Allah yang kudus. Selama hidup di dunia maka orang-orang

${ }^{6}$ William F. Arndt and F. Willbur Ginggrich, A Greek English Lexicon Of New Testament (Illinois: Cambidge University Press, n.d.), 571. 
percaya masih diperhadapkan dengan segala macam tawaran dunia yang memungkinkan orang-orang percaya jatuh ke dalam dosa. Harus diakui bahwa potensi orang-orang percaya untuk jatuh di dalam dosa sangatlah besar, hal ini dikarenakan tabiat berdosa masih tertinggal di dalam diri orang percaya sekalipun sudah lahir baru. Potensi-potensi inilah yang menjadi pergumulan batin orang-orang percaya untuk terus menerus berjuang melawan dosa.

Orang-orang percaya tidak terluput dari perbuatan dosa. Namun dalam hal ini bukan berarti bahwa sesuatu yang menjadi kewajaran jikalau orang-orang percaya terus menerus hidup di dalam dosa. Rasul Paulus menuliskan dalam suratnya kepada jemaat di Korintus bahwa orang percaya yang terus menerus hidup dalam dosa "tidak akan mendapat bagian dalam kerajaan Allah" (1 Kor. 6:10). Oleh sebab itu semestinya orang-orang yang telah memperoleh pengudusan secara posisi harus memiliki penyerahan diri yang mutlak kepada Allah, menganggap pengudusan secara pengalaman sebagai proses dalam penderitaan yang indah untuk mendapatkan kesempurnaan.

\section{Proses dalam Penyerahan Diri Kepada Allah}

Penyerahan diri kepada Allah dalam hal ini bukan berarti orang-orang percaya yang sudah dikuduskan menjadi pasif di dalam Allah sehingga tidak menjadi jatuh di dalam dosa. Tetapi yang dimaksud adalah bahwa penyerahan diri kepada Allah harus aktif dan berusaha untuk mengejar kekudusannya. Dalam Ibrani12:14 dikatakan "berusahalah hidup damai dengan semua orang dan kejarlah kekudusan, sebab tanpa kekudusan tidak seorangpun akan melihat Allah." Dalam nats ini menjelaskan bagaimana orang-orang percaya harus berusaha aktif bertindak dengan dorongan diri sendiri untuk mengejar kekudusan. Faktor internal sangat dibutuhkan untuk dapat menjalani proses pengudusan ini, namunpun demikian harus dikerjakan dalam penyerahan diri yang mutlak kepada Allah yang menjadi faktor external dari proses pengudusan orang-orang percaya tersebut.

Ketidak terlibatan Allah dan kurangnya penyerahan diri dalam proses pengudusan hidup orang percaya akan mengakibatkan orang-orang percaya mudah jatuh di dalam dosa. Tidak jarang hal ini menimbulkan berbagai pertanyaan dalam diri orang-orang percaya, "Mengapa masih selalu berdosa setelah Allah menyelamatkan seseorang dari dosa-dosanya?" Billy Graham mengatakan bahwa hal itu sebetulnya kelihatan aneh tetapi kondisi itu merupakan sesuatu yang patut disyukuri. Itupun merupakan bukti bahwa Roh Kudus telah masuk ke dalam hidup seseorang yang telah percaya sehingga menerangi kegelapan dosa dan menjadikan orang percaya peka terhadap dosa. ${ }^{7}$

Kehidupan yang lama sebelum bertobat merupakan kehidupan yang penuh dosa. Hal ini tidak disadari oleh orang-orang percaya karena masih diselubungi oleh dosa. Seseorang hidup di lingkungan orang-orang yang tidak percaya, namun ia tidak merasa terganggu oleh karena berada dalam situasi dan kondisi yang serupa. Tozer mengatakan : Seseorang tidak merasa kecewa ketika mendapatkan bahwa apa yang disampaikan gurunya itu tidak semuanya benar, atau pendapat para politikus tidak setia atau para pedagang tidak sepenuhnya jujur atau teman-teman tidak sepenuhnya dapat dipercaya. ${ }^{8}$ Oleh sebab itu ketika seseorang berada dalam Kristus, sudah lahir baru, maka sudut pandangnya akan mengalami perbedaan. Ada berbagai perjuangan yang dilakukan supaya dosa tidak lagi menguasai hidupnya. Rasul

\footnotetext{
${ }^{7}$ Billy Graham, Roh Kudus (Bandung: Lembaga Literatur Baptis, 2000), 122.

${ }^{8}$ A.W .Tozer, Mengenal Yang Maha Kudus (Bandung: Kalam Hidup, 1993), 146.
} 
paulus mengatakan bahwa perjuangan orang-orang percaya "bukanlah perjuangan melawan darah dan daging, tetapi melawan pemerintah-pemerintah, melawan penguasa-penguasa, melawan penghulu-penghulu dunia yang gelap ini, melawan roh-roh jahat di udara. (Ef. 6:12).

Di dalam dunia ini ada satu kekuatan roh yang tidak berasal dari Allah yang sedang bekerja. "Roh" ini bahkan berusaha menjauhkan orang-orang percaya dari Allah dan kehendak-Nya. "Roh" ini bukan hanya berasal dari Iblis akan tetapi sifat dasar manusia berdosa yang ada dalam diri orang percaya juga ikut bekerja. "Sebab keinginan daging berlawanan dengan keinginan roh dan keinginan Roh berlawanan dengan daging...karena keduanya bertentangan sehingga kamu setiap kali tidak melakukan apa yang kamu kehendaki" (Gal. 5:17). Oleh sebab itu orang-orang percaya harus bergerak aktif dan tidak memberi kesempatan kepada keinginan daging dan iblis untuk menguasainya (Ef. 4:27). Membuang segala sesuatu yang jahat dan tidak kudus (1 Pet. 1:2). Menurut Thiessen, jika penyerahan yang mula-mula tidak diikuti dengan setia, maka terlebih dahulu hidup ini dipersembahkan dengan pasti kepada Allah sebelum kesucian praktis dimungkinkan (Rom. 6:13;12:1-2); tetapi apabila orang percaya itu telah menyerahkan diri sepenuhnya kepada Allah maka perkembangan pengudusan Allah pasti. ${ }^{10}$

Penyerahan diri yang sepenuhnya kepada Allah memberikan suatu kepastian bahwa orang percaya tersebut pasti dimampukan oleh Allah untuk melewati proses demi proses yang terjadi dalam hidupnya. Melalui pimpinan Roh Kudus maka ia akan dituntun untuk hidup sesuai dengan firman Tuhan. Roh kudus akan memberikan kehidupan kepada tubuhnya dan membawanya kembali dari rasa mati dosa (Rom. 8:11). Dan membawa hidup baru yang berkelimpahan dalam Kristus. Hidup merupakan sesuatu yang istimewa jika dijalani dibawah bimbingan Roh Kudus. Hidup yang istimewa dan penuh makna diperoleh oleh karena orangorang percaya meletakkan dasar atau tujuan hidupnya di dalam kehendak Allah yang kudus lewat firman-Nya. Hidupnya tak lagi digerogoti oleh iblis dan keinginan-keinginan daging di dalam dirinya. ${ }^{11}$ Dosa tidak lagi menguasai hidupnya dan seluruh anggota tubuhnya dipersembahkan sebagai senjata kebenaran Allah (Rom. 6:12-14).

\section{Proses Dalam Penderitaan yang Indah}

Pada masa sekarang ini, ada banyak orang yang menolak penderitaan. Bigman Sirait mengatakan, bahwa manusia zaman cenderung menolak penderitaan sekarang lantaran berada dalam cengkraman egoisme. ${ }^{12}$ Dalam keegoisan, manusia akan menyambut dengan penuh antusias kebahagiaan dan menolak mentah-mentah penderitaan. Egoisme membuat manusia menerima hanya apa yang diinginkan orang lain, termasuk yang dikehendaki Tuhan. Orangorang percaya juga tidak terlepas dari egoisme ini dan melupakan bahwa semestinya harus merelakan diri dalam setiap bentuk proses yang dialami selama di dunia. Orang-orang percaya melupakan bahwa ketika ada penyerahan diri yang total kepada kehendak Allah maka akan menimbulkan pengalaman-pengalaman lain, yang sifatnya berbeda-beda, baik secara rohani maupun secara jasmani.

\footnotetext{
${ }^{10}$ Henry C. Thiessen, Teologi Sistimatika (Malang: Gandum Mas, 1997), 446.

${ }^{11}$ Sonny Zaluchu, "Respons Tests of Leadership Menurut Teori Frank Damazio Pada Mahasiswa Pascasarjana Jurusan Kepemimpinan Kristen STT Harvest Semarang," Jurnal Jaffray 16, no. 2 (2018): 145, https://ojs.sttjaffray.ac.id/index.php/JJV71/article/view/289/pdf_173.

${ }^{12}$ Bigman Sirait, "Reformata" (Jakarta, 2004).
} 
Pengalaman-pengalaman yang bersifat rohani yang dialami oleh orang-orang percaya biasanya selalu mendatangkan penderitaan, dan hal ini Alkitabiah. Disebut Alkitabiah karena pada kenyataannya Alkitab tidak menuliskan bahwa ketika percaya dan dikuduskan di dalam Kristus maka semua orang-orang percaya akan secara terus menerus hidup di dalam kebahagiaan. Justru rasul Paulus mengatakan harus bersukacita dalam penderitaan sebab "penderitaan adalah anugerah yang dikaruniakan-Nya" (band. 2 Kor. 7:4; Kol. 1:24), dan layak disyukuri karena penderitaan itu hanya bersifat sementara (band. 2 Kor. 4:17). Sesungguhnya Rasul Paulus memandang bahwa pengudusan secara pengalaman adalah penderitaan yang indah. Paulus berkata oleh karena ia telah merasakan sendiri bagaimana hidupnya setelah ditangkap oleh Kristus.

Ketika Paulus mengatakan menjadi "ciptaan baru" (2 Kor. 5:17) bukan berarti telah menjadi sempurna atau tanpa cacat cela atau bebas dari kemarahan, rasa sakit atau penderitaan dan dijauhkan dari pengalaman hidup yang keras. Namun dalam hal ini yang dimaksudkan dengan ciptaan baru adalah menjalani kehidupan yang berpaling kepada Allah yang kasih karunia-Nya telah menebus manusia kembali melalui Kristus.

Hal ini memberikan penjelasan bahwa pengudusan yang diperoleh bukanlah sesuatu yang sempurna dan tanpa cacat cela. Di dalam Perjanjian Lama, hampir semua tokoh-tokoh Perjanjian Lama tidak terlepas dari ketidaksempurnaan. Nuh merupakan orang yang dipandang benar oleh Allah bukanlah seorang yang sempurna tanpa dosa karena ia pernah mabuk secara memalukan (Kej. 9:20-27). Demikian juga Ayub yang disebut saleh banyak hal berupa keluhan-keluhan yang membawa ia berdosa di hadapan Allah.

Selain itu bangsa Israel sebagai bangsa yang dikuduskan oleh Allah ternyata tidak tahan terhadap batu ujian yang diberikan Allah kepada mereka. Bangsa Israel menjadi bangsa yang memberontak oleh karena tidak tahan dalam penderitaan. Sedikit saja tantangan yang mereka alami maka mereka bersungut-sungut di hadapan Allah (Kel. 61:12-13). Bangsa Israel tidak menyadari bahwa proses yang sedang mereka alami merupakan seijin Allah dan jika mereka melewatinya maka membuat mereka semakin indah dihadapan Tuhan.

Di dalam Perjanjian Baru hal ini juga terlihat dalam kehidupan orang-orang Yahudi. Mereka lebih senang memelihara Taurat Musa dari pada percaya kepada Kristus. Namun demikian orang-orang Yahudi bukan berarti tidak ada yang percaya. Bagi mereka yang sebagian besar juga menerima surat Paulus dianjurkan untuk terus bertahan dalam proses yang sedang mereka alami. Rasul Petrus dalam suratnya menuliskan "Jadi karena Kristus telah menderita penderitaan badani, kamu juga harus mempersenjatai dirimu dengan pikiran yang demikian, karena barang siapa yang telah menderita penderitaan badani, ia telah berhenti berbuat dosa (1 Pet. 4:1).

Penderitaan Kristus secara jasmani bukan lagi sesuatu yang asing di dalam kehidupan orang-orang percaya; hal ini merupakan dasar dari iman percaya yang sesungguhnya. ${ }^{13}$ Tetapi mengenai kalimat "Barang siapa yang telah menderita penderitaan badani dia telah berhenti berbuat dosa" menunjukkan bahwa jika orang percaya memiliki perilaku yang seperti ini, maka penderitaan akan membuat mereka tidak menjalani sisa hidup mereka di bumi untuk melakukan keinginan manusia jahat, melainkan kehendak Allah. ${ }^{14}$

\footnotetext{
${ }^{13}$ Sonny Eli Zaluchu, "Penderitaan Kristus Sebagai Wujud Solidaritas Allah Kepada Manusia," DUNAMIS ( Jurnal Teologi dan Pendidikan Kristiani ) Vol 2, no. 1 (2017): 61-74.

${ }^{14}$ Peter H. David, Ucapan Yang Sulit Dalam Perjanjian Baru (Malang: SAAT, 2001), 210-211.
} 
Ketika Paulus berkata dalam tentang "melupakan apa yang telah di belakang" (Fil 3:1314), hal tersebut untuk dapat memenuhi panggilan surgawi dari Allah. Yang terpenting dari semua itu adalah bahwa apa yang telah terjadi di masa lalu biarlah berlalu dan hidup yang sekarang harus diarahkan pada tujuan yang jelas. Dalam hidup harus berlomba untuk mengejar panggilan surgawi dari Allah. Dan ketika telah melewatinya hal inilah yang dikatakan Paulus sebagai proses yang indah. Orang percaya saat ini harus terus mengejar, bertumbuh dan berbuah.

Zaman sekarang banyak orang yang melakukan hal-hal terlarang atas nama kemerdekaan. Kemerdekaan atau kebebasan disalahtafsirkan; mereka menggunakan kemerdekaan untuk kebebasan dan berbuat dosa. Ada kecenderungan untuk sekadar mendapatkan keuntungan, meningkatkan kenikmatan atau popularitas. Banyak orang mencapai titik kesenangan di mana mereka mulai "berhenti" dari pada maju bertumbuh. Mereka menetapkan standar hidup pribadi mereka dengan membandingkan diri dengan orang lain, atau sesuatu yang dirasa cocok. Pada titik ini, mereka berhenti mencari Allah untuk mengenal siapakah Dia dan mulai mengejar keuntungan. Pusat perhatian mereka mulai beralih dan mulai sesat di hati. ${ }^{13}$

Salah satu pengertian dari pengudusan adalah "berada di dalam keadaan murni." Proses yang dikatakan oleh Rasul Paulus sebagai proses dalam penderitaan yang indah memberi hasil yang murni yang menuju kepada kesempurnaan. Sekalipun dalam Perjanjian Lama Allah sangat menekankan kekudusan terhadap umat-Nya Israel. Namun dalam hal ini kekudusan dalam standar Allah adalah sesuatu yang mustahil dilakukan oleh orang-orang percaya dengan sempurna, sebab tidak ada seorangpun yang dapat mencapai kesempurnaan sama seperti Allah. Hanya Yesus Kristuslah yang telah menyempurnakan semua itu melalui karyaNya di kayu salib.

\section{Peranan Roh Kudus dalam Pengudusan secara Pengalaman}

Di dalam Galatia 5:25, Rasul Paulus menuliskan:"Jika kita hidup oleh Roh baiklah hidup kita juga dipimpin oleh Roh." Dari nats ini dapat diambil suatu makna di dalamnya bahwa sebagai orang-orang yang sudah bertobat dan lahir baru, maka Roh Kudus telah berdiam dalam dirinya dan turut bekerja untuk menghasilkan buah yang baik. Orang-orang percaya didorong untuk memberi dirinya dipimpin oleh Roh supaya dapat mengalami pertumbuhan rohani yang lebih baik.

Salah satu peranan Roh Kudus yang sudah berdiam dalam hidup orang percaya adalah memberi pertumbuhan. ${ }^{15}$ Roh Kudus memimpin dalam segala kebenaran untuk menuju kepada pengudusan yang sempurna. Memang hidup yang dipimpin oleh Roh kudus merupakan hal yang sangat berat sekali untuk dilalui oleh setiap orang percaya. Namun dalam hal ini jika tidak dipimpin oleh Roh dengan kata lain mengandalkan kekuatan sendiri, maka pengudusan secara pengalaman tidak akan berlangsung dalam hidup orang percaya.

Setiap pekerjaan yang didorong oleh karena kehendak dari diri sendiri, walaupun mungkin hasilnya dapat memberi kepuasan namun sifatnya sementara. Sifat yang sementara inilah yang mudah memberi kekecewaan bagi orang-orang percaya, sehingga mudah sekali

\footnotetext{
${ }^{13}$ John Bevere, Kemenangan Di Padang Belantara (Semarang: Media Injili Kerajaan, 2002), 80.

${ }^{15}$ Asih Rachmani Endang Sumiwi, "Pembaharuan Pikiran Pengikut Kristus Menurut Roma 12:2," Jurnal Teologi Berita Hidup 1, no. 1 (2018): 46-55, www.e-journal.sttberitahidup.ac.id/index.php/jbh.
} 
jatuh dalam dosa. Tetapi jikalau hidup dipimpin oleh Roh, maka orang-orang percaya demikian akan menikmati hasil yang baik. Didalam Yohanes 15, Rasul Yohanes mengatakan bahwa orang percaya yang bertumbuh dan memiliki buah adalah orang percaya yang tinggal di dalam Kristus dan bergantung kepada-Nya serta Roh Kudus bekerja didalam hidupnya.

\section{Mematikan Segala Perbuatan Daging}

Ketika seseorang dipimpin oleh Roh, maka pada saat itu sebenarnya orang-orang percaya dapat mematikan segala perbuatan daging yang ada didalam dirinya. Roh kudus yang telah tinggal didalam diri orang-orang percaya selalu berada didalam peperangan melawan pemikiran daging manusia. Galatia 5:16-18 menjelaskan bahwa orang yang dipimpin oleh Roh, tidak akan menuruti keinginan-keinginan daging, sebab keinginan daging berlawanan dengan keinginan Roh. Keinginan Roh adalah menuju pada kehendak Allah sedangkan keinginan daging adalah kebalikkannya menuju pada kebinasaan.

Setiap orang percaya oleh Roh, maka akan memiliki ciri-ciri: Senantiasa mengucap syukur (Ef. 5:18-20); senang bersaksi (Kis 2:4); senang berdoa (Kis 2:42b); haus akan Firman Allah (Kis 2:42a); berhasil di dalam pelayanan (Kis 2:47); menginsafi akan kehadiran Kristus (Yoh. 14:20); buah Roh nyata dalam hidupnya (Ef. 4:22); karunia-karunia Roh nyata dalam hidupnya (Kis. 2:43); mengingini hidup suci (Kis 4:31); menyadari pimpinan Roh Kudus (Yoh. 14-16-18); mengasihi (Kis 2:44-45). ${ }^{15}$ Setiap orang yang sudah percaya dan bertumbuh, akan terlihat dalam sikap hidupnya bahwa ia adalah orang yang telah dipimpin oleh Roh.

\section{Memberi Kemenangan dalam Hidup Orang Percaya}

Sekalipun di dalam hidup orang percaya tidak pernah mencapai titik di mana orang tidak pernah berbuat dosa, namun jika dalam hidup ini mampu mengatasi segala keinginan daging dan bertumbuh dalam Kristus, maka orang-orang percaya dapat disebut sebagai orang-orang pemenang. Ironis, jika dalam perlombaan seseorang mengalami kekalahan. Namun, jika berlomba dengan gigih dan akhirnya mencapai garis finish, itulah yang memberi kemenangan dalam hidup orang percaya. Untuk mendapatkan kemenangan ini, tentu tidak terlepas dari pekerjaan Roh Kudus. Mulai dari pertama sekali lahir baru sampai pada proses demi proses yang dilalui dalam hidup, orang percaya terus-menerus dituntun oleh Roh Kudus sampai mendapatkan kemenangan. Hal tersebut sesuai dengan apa yang dikatkan Paulus dalam 1 Korintus 15:57, "Tetapi syukur kepada Allah yang telah memberikan kepada kita kemenangan oleh Yesus Kristus Tuhan kita."

Setiap orang yang sudah dikuduskan secara posisi memiliki status yang sudah terjamin di dalam Kristus. Statusnya dinyatakan terjamin karena dasar pengudusan secara posisi yang telah ia peroleh berdasarkan iman dan percaya di dalam Kristus. Namun meskipun demikian bukan berarti pengudusan secara posisi yang telah diperoleh oleh orang-orang percaya akan berhenti sampai di situ saja, melainkan secara terus menerus orang percaya akan mengalami proses pengudusan. Proses pengudusan yang dialami oleh setiap orang percaya setiap harinya sesuai dengan pengalaman hidup sehari-hari. Proses pengudusan inilah yang disebut dengan pengudusan secara pengalaman (progressive sanctification).

\footnotetext{
${ }^{15}$ Ichwei. G. Indra, Teologi Sistematika (Bandung: Yayasan Baptis Indonesia, 1999), 165-166.
} 
Pengudusan melalui pengalaman adalah penting, karena selama hidup di dunia, orangorang percaya tidak pernah terlepas dari setiap dosa dan pelanggaran dihadapan Allah. Hal ini memberi arti bahwa orang-orang percaya yang sudah disucikan secara posisi belum mendapat penyucian secara sempurna. Misalkanlah umat Israel yang mendapat pengudusan secara posisi dari Allah secara langsung tetapi tidak dapat memenuhi kriteria untuk menjadi bangsa yang kudus seperti yang Allah inginkan sehingga mereka mengalami penundaan pengudusan, ataupun jemaat Korintus yang sudah memperoleh pengudusan secara posisi oleh karena percaya kepada pengorbanan Yesus Kristus, tetapi mereka tetap hidup dalam perbuatan dosa.

Untuk mendapatkan pengudusan yang terus menerus, maka orang-orang yang sudah percaya yang sudah jatuh di dalam dosa harus terlebih dahulu melakukan pemberesan. Pemberesan merupakan hal yang diinginkan oleh Allah bagi umat-Nya, baik dalam Perjanjian Lama maupun dalam Perjanjian Baru. Allah menginginkan adanya sebuah pengakuan (homologeo) yang tulus karena telah melanggar perintah Allah atau melakukan dosa dihadapan Allah, (Im. 5:6; 1; Yoh. 1:9).

\section{Kesimpulan}

Pengudusan secara pengalaman merupakan proses bagi orang-orang percaya. Dikatakan proses, sebab selama nafas dikandung badan, masih banyak tantangan-tantangan yang dihadapi oleh orang-orang percaya, secara khusus dalam hal berbuat dosa. Sekalipun identitas seseorang itu adalah pengikut Kristus, kecenderungan berbuat dosa masih ada. Selama masih memiliki tubuh jasmaniah atau tubuh fana ini, maka orang-orang percaya akan terus bergumul untuk melawan kuasa dosa dan keinginan daging dalam dirinya. Orang-orang percaya harus tetaplah bertahan dalam penderitaan dan menganggap penderitaan yang dialami sebagai sesuatu yang patut disyukuri. Dalam penyerahan diri yang total kepada Allah, maka Roh Kudus akan menolong, membimbing dan menjaga orang-orang percaya dalam setiap pengalaman-pengalaman mereka, sehingga pengalaman-pengalaman mereka berkenan kepada Allah. Roh Kudus juga yang menolong memberi pertumbuhan, sehingga orang-orang percaya memberi buah yang baik dalam pengalaman hidup mereka. Apabila orang-orang percaya jatuh dalam perbuatan dosa, maka Roh Kudus yang telah berdiam tetap dalam hidup orangorang percaya akan senantiasa menginsafi sehingga orang-orang percaya menyadari dan mengakui (homologeo) kesalahan dan dosa yang telah diperbuat dihadapan Tuhan. Proses demi proses inilah yang akan semakin memurnikan orang-orang percaya untuk mendapatkan kesempurnaan.

\section{Referensi}

A.W .Tozer. Mengenal Yang Maha Kudus. Bandung: Kalam Hidup, 1993.

Bigman Sirait. "Reformata." Jakarta, 2004.

Billy Graham. Roh Kudus. Bandung: Lembaga Literatur Baptis, 2000.

Chris Marantika. Doktrin Keselamatan Dan Kehidupan Rohani. Yogyakarta: Iman Press, 2002.

Henry C. Thiessen. Teologi Sistimatika. Malang: Gandum Mas, 1997.

Ichwei. G. Indra. Teologi Sistematika. Bandung: Yayasan Baptis Indonesia, 1999.

James Strong. The New Strong's Exhaustive Concordance, n.d.

John Bevere. Kemenangan Di Padang Belantara. Semarang: Media Injili Kerajaan, 2002. 
Murray-Swank, Nichole A., Kenneth I. Pargament, and Annette Mahoney. "At the Crossroads of Sexuality and Spirituality: The Sanctification of Sex by College Students." The International Journal for the Psychology of Religion 15, no. 3 (2005).

Pardede, Zulkisar. "Rancang Bangun Teologi ' Kekudusan' Tentang Hamba Tuhan Sebagai Pemimpin Kristen Menurut Kitab Yosua.” KHARISMATA: Jurnal Teologi Pantekosta 1, no. 2 (2019): 100-117. http://www.ejournal.stajember.ac.id/index.php/kharismata/article/view/20.

Peter H. David. Ucapan Yang Sulit Dalam Perjanjian Baru. Malang: SAAT, 2001.

Santo, Joseph Christ. "Makna Dan Penerapan Frasa Mata Hati Yang Diterangi Dalam Efesus 1:18-19.” Jurnal Teologi Berita Hidup 1, no. 1 (2018): 1-12. www.ejournal.sttberitahidup.ac.id/index.php/jbh.

Siahaan, Harls Evan R. "Karakteristik Pentakostalisme Menurut Kisah Para Rasul.” DUNAMIS: Jurnal Teologi dan Pendidikan Kristiani 2, no. 1 (2017): 12-28. www.sttintheos.ac.id/e-journal/index.php/dunamis.

Sumiwi, Asih Rachmani Endang. "Pembaharuan Pikiran Pengikut Kristus Menurut Roma 12:2." Jurnal Teologi Berita Hidup 1, no. 1 (2018): 46-55. www.ejournal.sttberitahidup.ac.id/index.php/jbh.

Tiyono, Dolf. "Memahami Imago Dei Sebagai ' Golden Seed ."” EPIGRAPHE: Jurnal Teologi dan Pelayanan Kristiani 1, no. 1 (2017): 39-54. http://www.stttorsina.ac.id/jurnal/index.php/epigraphe/article/view/8.

W.E. Vine. Vine Expository Dictionary of Old \& New Testament Words, n.d.

William D. Mounce. The Analytical Lexikon To The Greek. Michigan: London Pub.House, 1993.

William F. Arndt, and F. Willbur Ginggrich. A Greek English Lexicon Of New Testament. Illinois: Cambidge University Press, n.d.

Wiryadinata, Halim. “A Critical Analysis of God ' S Righteousness in Romans 1 : 16 -17.” KURIOS (Jurnal Teologi dan Pendidikan Agama Kristen) 2, no. 1 (2014): 16-17. www.sttpb.ac.id/e-journal/index.php/kurios.

"An Understanding the Pauline Christology Significance of Firstborn (Protokos) In The Light of Paschal Theology : Critical Evaluation on Colossian 1 : 15-20." KURIOS (Jurnal Teologi dan Pendidikan Agama Kristen) 4, no. 1 (2018): 14-25. http://www.sttpb.ac.id/e-journal/index.php/kurios/article/view/33.

Zaluchu, Sonny. "Respons Tests of Leadership Menurut Teori Frank Damazio Pada Mahasiswa Pascasarjana Jurusan Kepemimpinan Kristen STT Harvest Semarang." Jurnal Jaffray 16, no. 2 (2018): 145. https://ojs.sttjaffray.ac.id/index.php/JJV71/article/view/289/pdf_173.

Zaluchu, Sonny Eli. "Eksegesis Kisah Para Rasul 2:42-47 Untuk Merumuskan Ciri Kehidupan Rohani Jemaat Mula-Mula Di Yerusalem.” EPIGRAPHE: Jurnal Teologi dan Pelayanan Kristiani 2, no. 2 (2018): 72-82. Accessed November 1, 2018. http://www.stttorsina.ac.id/jurnal/index.php/epigraphe.

—_. "Penderitaan Kristus Sebagai Wujud Solidaritas Allah Kepada Manusia." DUNAMIS ( Jurnal Teologi dan Pendidikan Kristiani ) Vol 2, no. 1 (2017): 61-74. 